\title{
IMPACTS OF PROJECTED CHANGES OF EMISSIONS AND CLIMATE ON FUTURE U.S. AIR QUALITY
}

\author{
Y. ZHANG, K. WANG, K. YAHYA, P. CAMPBELL \& C. JENA \\ North Carolina State University, U.S.A.
}

\begin{abstract}
Projected changes in emissions and climate will impact future air quality and related human and environmental health. In this work, an advanced online-coupled meteorology and chemistry model, the Weather Research and Forecasting Model with Chemistry (WRF/Chem), has been applied to the continental U.S. for current (2001-2010) and future (2046-2055) decades under four emission/ climate scenarios including the Representative Concentration Pathways (RCP) 4.5 and 8.5 that regulate future radiative forcing and the Technology-driven model (TDM) A1B and B2 that explicitly simulate the relationship between the socioeconomic variables and technological changes. A comprehensive evaluation has been performed for current decade using available observations from surface networks and satellites and shows an overall good performance in reproducing observations. The future decadal simulations show that future climate features with stronger radiation, higher surface temperature and planetary boundary layer height, and enhanced precipitation under all scenarios, with less warming and drier atmosphere by RCP4.5 than 8.5 and by TDM B2 than A1B. The simulations under RCP8.5/TDM A1B show the enhanced future $\mathrm{O}_{3}$ levels, which are attributed to warmer climate, higher emissions of methane $\left(\mathrm{CH}_{4}\right)$ and biogenic volatile organic compounds (VOCs), and dis-benefit of nitrogen oxides $\left(\mathrm{NO}_{\mathrm{x}}\right)$ reduction in VOC-limited regime. The latter factor offsets the benefits of reduced emissions of $\mathrm{NO}_{\mathrm{x}}$ and anthropogenic VOCs. Future air quality features greater reduction in $\mathrm{PM}_{2.5}$ by $\mathrm{RCP} 4.5 / 8.5$ than TDM B2/A1B and decreased $\mathrm{O}_{3}$ over most areas by RCP4.5 and TDM B2, indicating the benefits of carbon policy and technology changes with greater emission reductions and the importance of win-win emission control strategies in mitigating air pollution and adverse climate change.
\end{abstract}

Keywords: climate change, climate scenarios, decadal application and evaluation, future air quality, technology-driven model, WRF/Chem.

\section{INTRODUCTION}

Changes in anthropogenic and biogenic emissions as well as climate will affect future air quality, which in turn affects human health, environment, and ecosystem. Numerous studies have reported projected emissions and/or climate change and the resulting air quality over continental U.S. (CONUS) and its subdomains [1-10]. Table 1 summarizes the model systems, domains, horizontal and vertical grid resolutions used in a number of past studies.

In this work, an advanced online-coupled meteorology and chemistry model, the Weather Research and Forecasting Model with Chemistry (WRF/Chem) [11-12], has been applied to CONUS for current (2001-2010) and future (2046-2055) decades under four emission/climate scenarios including the Representative Concentration Pathways (RCP) 4.5 and 8.5 that regulate future radiative forcing [13-14] and the Technology-driven model (TDM) A1B and B2 [15] that explicitly simulate the relationship between the socioeconomic variables and technological changes. The objective is to quantify the impact of projected changes in 
Table 1: Studies on the effects of future climate on air quality over U.S.

\begin{tabular}{|c|c|c|c|}
\hline Reference & Model systems & $\begin{array}{l}\text { Domain and } \\
\text { horizontal and vertical } \\
\text { grid resolution }\end{array}$ & Simulation period \\
\hline Hogrefe et al. [1] & $\begin{array}{l}\text { MM5/CMAQ } \\
\text { v4.2 }\end{array}$ & $\begin{array}{l}\text { Eastern U.S.; } 36-\mathrm{km} \text {, } \\
16 \text { layers }\end{array}$ & $\begin{array}{l}\text { Summer (June-August } \\
\text { (JJA)) for 1993-1997, } \\
\text { 2023-2027, 2053-2057, } \\
\text { and 2083-2087 }\end{array}$ \\
\hline Tagaris et al. [2] & MM5/CMAQ & $\begin{array}{l}\text { CONUS; } 36-\mathrm{km}, 9 \\
\text { layers up to } 15 \mathrm{~km}\end{array}$ & $\begin{array}{l}\text { Annual: } 2001 \text { and } 2050 \text {, } \\
\text { summer: } 2001-2002 \text { and } \\
\text { 2049-2051 }\end{array}$ \\
\hline Zhang et al. [3] & $\begin{array}{l}\text { MM5 v3.7/ } \\
\text { CMAQ v4.4 }\end{array}$ & $\begin{array}{l}\text { CONUS; } 36-\mathrm{km}, 14 \\
\text { layers up to } 16 \mathrm{~km}\end{array}$ & $\begin{array}{l}\text { Summers: } 2001 / 2002 \text { and } \\
2051 / 2052\end{array}$ \\
\hline Wu et al. [5] & $\begin{array}{l}\text { GISS GCM 3/ } \\
\text { GEOS-Chem }\end{array}$ & $\begin{array}{l}\text { CONUS; } 4^{\circ} \times 5^{\circ}, 23 \\
\text { layers }\end{array}$ & $\begin{array}{l}\text { 1999-2001 and 2049- } \\
2051\end{array}$ \\
\hline Nolte et al. [4] & $\begin{array}{l}\text { MM5/CMAQ } \\
\text { v4.5 }\end{array}$ & $\begin{array}{l}\text { CONUS; 36-km, } 14 \\
\text { layers }\end{array}$ & $\begin{array}{l}1999-2003 \text { and } 2048- \\
2052\end{array}$ \\
\hline Dawson et al. [6] & MM5/PMCAMx & Eastern U.S.; 36-km & $\begin{array}{l}\text { January and July of } \\
2001-2005 \text { and } 2050\end{array}$ \\
\hline Pye et al. [7] & $\begin{array}{l}\text { GISS GCM III/ } \\
\text { GEOS-Chem } \\
\text { v.7-4-11 }\end{array}$ & $\begin{array}{l}\text { CONUS; } 4^{\circ} \times 5^{\circ}, 23 \\
\text { layers }\end{array}$ & $\begin{array}{l}\text { 1999-2001 and 2049- } \\
2051\end{array}$ \\
\hline Lam et al. [8] & $\begin{array}{l}\text { MM5/CMAQ } \\
\text { v4.6 }\end{array}$ & $\begin{array}{l}\text { CONUS at } 36-\mathrm{km} / \\
\text { nested southeastern } \\
\text { U.S. at 12-km,14 } \\
\text { layers }\end{array}$ & 2002 and 2050 \\
\hline Gao et al. [9] & $\begin{array}{l}\text { WRF v3.2.1/ } \\
\text { CMAQ v5.0 }\end{array}$ & $\begin{array}{l}\text { CONUS; } 12-\mathrm{km} \text { and } \\
14 \text { layers }\end{array}$ & $\begin{array}{l}2001-2004 \text { and 2057- } \\
2059\end{array}$ \\
\hline Penrod et al. [10] & $\begin{array}{l}\text { WRF v3.2CMAQ } \\
\text { v5.0 }\end{array}$ & $\begin{array}{l}\text { CONUS; } 36-\mathrm{km} \text { and } \\
14 \text { layers up to } 15 \mathrm{~km}\end{array}$ & $\begin{array}{l}\text { Summer (JJA) and winter } \\
\text { (December, January, } \\
\text { February (DJF)) of 2001- } \\
2005 \text { and 2026-2030. }\end{array}$ \\
\hline This work & $\begin{array}{l}\text { WRF/Chem } \\
\text { v3.6.1/v3.7 }\end{array}$ & $\begin{array}{l}\text { CONUS; } 36-\mathrm{km} \text { and } \\
34 \text { layers up to } 16 \mathrm{~km}\end{array}$ & 2001-2010; 2046-2055 \\
\hline
\end{tabular}

emissions and climate on future air quality under most likely scenarios in support of policy making for air pollution control and adverse climate change mitigation.

This study distinguishes from past studies in two aspects. First, all past studies used offlinecoupled meteorological and chemistry models, e.g. the Penn State/NCAR Mesoscale Model (MM5) [16] and the Community Multiscale Air Quality (CMAQ) [17] that cannot simulate the feedbacks between meteorology and chemistry, which are important, particularly in predicting the impacts of future climate and emission changes on future air quality [18]. This study uses an online-coupled WRF/Chem that can simulate those feedbacks. Second, all past 
studies were conducted for 5-year or shorter time periods. The WRF/Chem simulations in this study are performed for a decade under current and future climate scenarios. While global model simulations on future climate were mostly performed for a period of 30-year or longer because of the use of simplified parameterizations for physics, dynamics, and chemistry that are computationally very efficient, full-coupled regional climate and chemistry models such as WRF/Chem contain very detailed representations of simulated atmospheric processes and thus computationally very expensive. Give current computational constraints, WRF/Chem simulations for a 10-year period therefore represents a significant advancement from previous studies with much shorter simulation periods.

\section{DESCRIPTION OF MODEL, SIMULATION, AND EVALUATION PROTOCOLS}

The model used in this study is the WRF/Chem v3.6.1 with updates in Wang et al. [12] for RCP simulations and v3.7 for TDM simulations. Gas-phase chemistry is a modified version of Carbon Bond 2005 (CB05) chemical mechanism with chlorine chemistry. Aqueous-phase chemistry is based on the AQ chemistry module (AQCHEM) for both resolved and convective clouds. The aerosol model is the Modal for Aerosol Dynamics in Europe with the Volatility Basis Set module for secondary organic aerosol (SOA) (MADE/VBS). The physics options include the Rapid and accurate Radiative Transfer Model for GCM (RRTMG) for both shortwave and longwave radiation, the Yonsei University (YSU) planetary boundary layer (PBL) scheme, the Morrison double moment microphysics scheme, as well as the Grell 3D Ensemble cumulus parameterization (for RCP simulations) and the multi-scale Kain Fritsch (MSKF) scheme (for TDM simulations). All model simulations use a horizontal resolution of 36-km over the CONUS domain and parts of Canada and Mexico, and a vertical resolution of 34 layers from the surface to $100-\mathrm{hPa}$. The model simulations are performed under four climate scenarios: RCP4.5 and 8.5, and TDM A1B and B2 for current (20012010) and future (2046-2055) decades. Given different emissions during 2001-2010 between the two RCP scenarios, two sets of 2001-2010 simulations are performed for the two RCP scenarios. For TDM A1B and B2, only one set of current period simulation is performed because their current-decade emissions are very similar. The anthropogenic emissions for current period RCP and TDM simulations are based on those of RCP and the U.S. National Emission Inventories (NEI), respectively. Biogenic, dust, and seal-salt emissions are calculated online. The chemical and meteorological initial and boundary conditions are based on simulations of Glotfelty et al. [19] using the modified Community Earth System Model (CESM)/Community Atmospheric Model (CAM) version 5.3 with updates from several studies [20-22].

A comprehensive evaluation for both climatological variables and chemical concentrations is performed using available observations from surface network and satellites during 20012010. The climatological evaluation is performed in terms of performance statistics, spatial distributions, and temporal variations based on 10-year averaged results during 2001-2010, following the protocols of Zhang et al. [23-25]. The statistical metrics include mean bias (MB), correlation coefficients (Corr), normalized mean bias (NMB) and normalized mean error (NME). The 10-year averaged results during the future and current periods are compared to examine the changes in climate and emissions and their impacts on future air quality. The projected changes in climate and air quality under the four climate scenarios are compared to assess the merits of carbon policy and technology changes in mitigating adverse climate change and air pollution. More detailed descriptions on model configurations, simulation design, and evaluation and analysis methodologies can be found in several studies [26-29]. 


\section{MODEL EVALUATION}

A number of meteorological and optical variables are evaluated. These include 2-m temperature (T2), 2-m relative humidity (RH2), 10-m wind speed (WS10), wind direction (WD10) against data from the National Climatic Data Center (NCDC), precipitation against data from NCDC, the National Acid Deposition Program (NADP), the Global Precipitation Climatology Project (GPCP), and the Parameter-elevation Regressions on Independent Slopes Model (PRISM), aerosol optical depth (AOD), cloud fraction (CF), cloud optical thickness (COT), cloud droplet number concentration (CDNC), and cloud water path (CWP) from the Moderate Resolution Imaging Spectroradiometer (MODIS), as well as downward shortwave radiation (SWDOWN), net shortwave radiation (GSW), downward longwave radiation (GLW), outgoing longwave radiation (OLR), and shortwave and longwave cloud forcing (SWCF and LWCF) against the Clouds and the Earth's Radiant Energy System (CERES).

WRF/Chem performs very well for $\mathrm{T} 2$ with $\mathrm{MBs}$ of $-0.3^{\circ} \mathrm{C},-0.4^{\circ} \mathrm{C}$, and $-0.6^{\circ} \mathrm{C}$ for RCP4.5, RCP8.5, and TDM A1B/B2, current-decade simulations, respectively. Precipitation is generally overpredicted over both land and ocean for RCP4.5 and 8.5 simulations with NMBs of $45 \%$ and $49.3 \%$ against NADP, $75.9 \%$ and $82.4 \%$ against GPCP, $34.6 \%$ and $37.6 \%$ against PRISM, and $189.8 \%$ and $126.1 \%$ against NCDC, respectively. By contrast, the TDM A1B/B2 simulation gives much better performance for precipitation with NMBs of $9 \%$ against NADP, $14.9 \%$ against GPCP, $11.5 \%$ against PRISM, and 59.1\% against NCDC, respectively. Such better agreement is because of the use of MSKF cumulus scheme in the TDM simulation which reduces high biases in precipitation predictions over ocean and coastal areas in the RCP simulations that use the Grell 3D cumulus parameterization. For all three sets of current simulations, WRF/Chem performs well for radiation variables including SWDOWN, GSW, GLW, and OLR (Corr $\geq 0.6$ and NMBs within $\pm 15 \%$ ). AOD and CDNC are moderately underpredicted, with NMBs of $-22 \%$ to $-13 \%$, and $-19.4 \%$ to $-15.2 \%$. The NMBs for $\mathrm{CF}$ for all simulations are within $\pm 14 \%$. While the RCP simulations show larger biases in SWCF and LWCF with NMBs of 20\%-20.3\% and 28\%-30.3\%, respectively, the TDM simulation shows a reduced bias with NMBs of $-13.3 \%$ and $0.3 \%$, respectively. Large biases exist for COT in all simulations with NMBs of $-43.9 \%,-43.3 \%,-53.9 \%$, respectively, for RCP4.5, RCP8.5, and TDM A1B/B2 simulations. Those results indicate high sensitivity to the cumulus parameterizations, and uncertainties in cloud dynamics and thermodynamics treatments.

The surface chemical variables evaluated in this study include maximum 1-hour and 8-hour $\mathrm{O}_{3}$ against the Clean Air Status and Trends Network (CASTNET) and Air Quality System (AQS), $\mathrm{PM}_{10}$ against $\mathrm{AQS}, \mathrm{PM}_{2.5}$ and $\mathrm{PM}_{2.5}$ species including sulfate $\left(\mathrm{SO}_{4}{ }^{2-}\right)$, ammonium $\left(\mathrm{NH}_{4}^{+}\right)$, nitrate $\left(\mathrm{NO}_{3}^{-}\right)$, elemental carbon (EC), organic carbon (OC) and total carbon (TC) against the Interagency for Monitoring Protected Visual Environments (IMPROVE) and the Speciated Trends Network (STN), dry deposition from CASTNET for sulfur dioxide $\left(\mathrm{SO}_{2}\right)$, nitric acid $\left(\mathrm{HNO}_{3}\right), \mathrm{SO}_{4}{ }^{2-}, \mathrm{NH}_{4}{ }^{+}$and $\mathrm{NO}_{3}{ }^{-}$, wet deposition from the National Atmospheric Deposition Program (NADP) for $\mathrm{SO}_{4}{ }^{2-}, \mathrm{NH}_{4}{ }^{+}$and $\mathrm{NO}_{3}^{-}$. In addition, satellite data are used to evaluate the column mass abundances of several species including carbon monoxide (CO) against Measurements of Pollution in the Troposphere (MOPITT), tropospheric ozone residual (TOR) against the Ozone Monitoring Experiment (OMI), and formaldehyde (HCHO) and nitrogen dioxide $\left(\mathrm{NO}_{2}\right)$ against SCIAMACHY.

$\mathrm{O}_{3}$ mixing ratios and $\mathrm{PM}_{2.5}$ concentrations are generally well predicted by WRF/Chem for both RCP4.5 and RCP8.5 cases with slight differences in model performance due to different emissions. For example, NMBs for max 8 -hour $\mathrm{O}_{3}$ are $-9.9 \%$ and $-11 \%$ against CASTNET and $4.9 \%$ and $3.5 \%$ against $\mathrm{AQS}$ for RCP4.5 and RCP8.5 simulations, respectively. NMBs 
for $\mathrm{PM}_{2.5}$ are $5.6 \%$ and $6.7 \%$ against IMPROVE and $13.2 \%$ and $13.8 \%$ against STN for RCP4.5 and RCP8.5 simulations, respectively. The TDM simulation gives similar good performance for $\mathrm{O}_{3}$ and $\mathrm{PM}_{2.5}$, with NMBs of max 8-hour $\mathrm{O}_{3}$ of $-8.9 \%$ against CASTNET and $2.3 \%$ against $\mathrm{AQS}$, and $\mathrm{NMBs}$ of $\mathrm{PM}_{2.5}$ of $12.9 \%$ against IMPROVE and $6.2 \%$ against STN. However, large biases exist in $\mathrm{PM}_{10}$ predictions, with $\mathrm{NMBs}$ of $-58.1 \%,-58.4 \%$, and $-48.8 \%$, respectively, for RCP4.5, RCP8.5, and TDM A1B/B2 simulations. This is due likely to underestimates in coarse $\mathrm{PM}$ emissions and in the growth rates of $\mathrm{PM}_{2.5}$ into coarse mode. For column variables, the model performance varies with species. For example, the two RCP simulations show moderate underpredictions for column CO and $\mathrm{HCHO}$ (NMBs of $-31.5 \%$ to $-17.9 \%$ ) but moderate-to-significant overpredictions for $\mathrm{NO}_{2}$ and TOR (NMBs of $33.1 \%$ 123.4\%). The overprediction in the column $\mathrm{NO}_{2}$ is attributed to overestimates in $\mathrm{NO}_{2}$ emissions. The overprediction in TOR may be caused by inaccurate boundary conditions used in upper layers.

\section{PROJECTED CLIMATE AND AIR QUALITY}

All future period simulations predict a warmer future with domain average increases by $\sim 2^{\circ} \mathrm{C}$ to $2.4^{\circ} \mathrm{C}$ in $\mathrm{T} 2$ due to increases in greenhouse gases (GHGs), SWDOWN, and GLW. Domain average WS10 increases by $0.04-0.05 \mathrm{~m} \mathrm{~s}^{-1}$. Precipitations are projected to increase by $0.2-0.4 \mathrm{~mm}^{-1} \mathrm{day}^{-1}$ over ocean and eastern U.S. PBL heights (PBLH) also increase over most parts of the U.S. due to the increase in T2 and radiation. While the increases in T2 can increase photochemical oxidation rates and biogenic emissions that in turn worsen $\mathrm{O}_{3}$ and PM pollution, the increases in precipitation, WS10, and PBLH will help to increase dispersion of pollutants, thus reducing their concentrations. The responses of future air quality reflect possible compensation among those variables.

Domain average $\mathrm{O}_{3}$ is projected to decrease by $2.2 \mathrm{ppb}$ and $1.6 \mathrm{ppb}$ under the RCP4.5 and TDM B2 scenarios but increase by $2.9 \mathrm{ppb}$ and $2.6 \mathrm{ppb}$ under the RCP8.5 and TDM A1B scenarios. Compared to the RCP4.5 and TDM B2 scenarios, the increases in future levels of $\mathrm{O}_{3}$ under the RCP8.5 and TDM A1B scenarios are mainly attributed to warmer climate, and emissions of methane $\left(\mathrm{CH}_{4}\right)$ and biogenic volatile organic compounds (VOCs). Another reason is the different responses of $\mathrm{O}_{3}$ chemistry to nitrogen oxides $\left(\mathrm{NO}_{\mathrm{x}}\right)$ emissions reduction. According to Zhang et al. [24], the $\mathrm{NO}_{\mathrm{x}}$-limited transition values for $\mathrm{NO}_{\mathrm{y}}$ and $\mathrm{O}_{3} / \mathrm{NO}_{\mathrm{y}}$ are $\leq 5$ $\mathrm{ppb}$ and $\geq 15$, respectively. Based on these indicators, the current-decade RCP4.5 and RCP8.5 simulations show mainly $\mathrm{NO}_{\mathrm{x}}$-limited regions over the western U.S. and VOC-limited regions over the eastern U.S. and over major cities and urban areas in the western U.S. However, the future-decade RCP4.5 simulation shows more $\mathrm{NO}_{\mathrm{x}}$-limited regions as compared to the future-period RCP8.5 simulation, which have more VOC-limited regions, especially over the eastern U.S. Significant decreases in $\mathrm{NO}_{\mathrm{x}}$ emissions result in decreases in $\mathrm{O}_{3}$ mixing ratios under the RCP4.5 scenario over most parts of the U.S. But over eastern U.S. under RCP8.5 scenario, $\mathrm{O}_{3}$ is VOC-limited, so reducing $\mathrm{NO}_{\mathrm{x}}$ emissions actually increases $\mathrm{O}_{3}$ formation (socalled dis-benefit). In addition, reducing $\mathrm{NO}_{\mathrm{x}}$ emissions lead to reduced $\mathrm{NO}$ titration in urban areas, thus indirectly increasing $\mathrm{O}_{3}$. The above dis-benefits of $\mathrm{NO}_{x}$ emission reduction offset the benefits of reduced emissions of $\mathrm{NO}_{\mathrm{x}}$ and anthropogenic VOCs under the RCP8.5 and TDM A1B scenarios.

All simulations predict reduced $\mathrm{PM}_{2.5}$ levels, with decrease of $0.6-1.6 \mathrm{mg} \mathrm{m}^{-3}$ in domain average $\mathrm{PM}_{2.5}$ concentrations, due mainly to reductions in primary $\mathrm{PM}$ emissions and emissions of precursors such as $\mathrm{SO}_{2}, \mathrm{NO}_{\mathrm{x}}$, and VOCs and for secondary PM. Greater reduction in $\mathrm{PM}_{2.5}$ by RCP4.5/8.5 than by TDM B2/A1B and decreased $\mathrm{O}_{3}$ over most areas by RCP4.5 and TDM B2 clearly indicate the benefits of carbon policy and technology changes with 
greater emission reductions. These results also have important policy implications. Since reducing $\mathrm{NO}_{x}$ emissions over VOC-limited regions can increase $\mathrm{O}_{3}$ formation, $\mathrm{NO}_{\mathrm{x}}$ emission control strategy much be implemented together with VOC emission reductions in order to reduce $\mathrm{O}_{3}$. The interplay and non-linear relationships between climatic and chemical variables and among chemical species indicate the importance of win-win emission control strategies in mitigating air pollution and adverse climate change.

\section{ACKNOWLEDGEMENTS}

This study is funded by the National Science Foundation EaSM program (AGS-1049200) at NCSU. The emissions for chemical species that are not available from the RCP emissions are taken from the 2008 NEI-derived emissions for 2006 and 2010 provided by the U.S. EPA, Environment Canada, and Mexican Secretariat of the Environment and Natural Resources (Secretaría de Medio Ambiente y Recursos Naturales-SEMARNAT) and National Institute of Ecology (Instituto Nacional de Ecología-INE) as part of the Air Quality Model Evaluation International Initiative (AQMEII). The projected emission growth factors from TDM A1B and B2 are provided from Fang Yan and David Streets, Argonne National Laboratory, U.S. The authors acknowledge use of the WRF-Chem preprocessor tool mozbc provided by the Atmospheric Chemistry Observations and Modeling Lab (ACOM) of NCAR and the script to generate initial and boundary conditions for WRF based on CESM results provided by Ruby Leung, PNNL. The authors acknowledge high-performance computing support from Yellowstone (ark:/85065/d7wd3xhc) provided by NCAR's Computational and Information Systems Laboratory, sponsored by the National Science Foundation and Information Systems Laboratory and the Extreme Science and Engineering Discovery Environment (XSEDE) (KRAKEN and STAMPEDE), which is supported by National Science Foundation grant number OCI-1053575.

\section{REFERENCES}

[1] Hogrefe, C., Lynn, B., Civerolo, K., Ku, J., Rosenthal, J., Rosenzweig, C., Goldberg, R., Gaffin, S., Knowlton, K. \& Kinney, P.L., Simulating changes in regional air pollution over the eastern United States due to changes in global and regional climate and emissions. Journal of Geophysical Research, 109(D22), D22301, 2004. http://dx.doi.org/10.1029/2004JD004690

[2] Tagaris, E., Manomaiphiboon, K., Liao, K., Leung, L.R., Woo, J., He, S., Amar, P. \& Russell, A.G., Impacts of global climate change and emissions on regional ozone and fine particulate matter concentrations over the United States. Journal of Geophysical Research, 112(D14), D14312, 2007. http://dx.doi.org/10.1029/2006JD008262

[3] Zhang, Y., Hu, X., Leung, L.R. \& Gustafson, ,Impacts of regional climate change on biogenic emissions and air quality. Journal of Geophysical Research, 113(D18), D18310, 2008. http://dx.doi.org/10.1029/2008JD009965

[4] Nolte, C.G., Gilliland, A.B., Hogrefe, C. \& Mickley, L.J., Linking global to regional models to assess future climate impacts on surface ozone levels in the United States. Journal of Geophysical Research, 113, D14307, 2008. http://dx.doi.org/10.1029/2007JD008497

[5] Wu, S., Mickley, L.J., Leibensperger, E.M., Jacob, D.J., Rind, D. \& Streets, D.G., Effects of 2000-2050 global change on ozone air quality in the United States. Journal of Geophysical Research, 113(D6), D06302, 2008. http://dx.doi.org/10.1029/2007JD008917 
[6] Dawson, J.P., Racherla, P.N., Lynn, B.H., Adams, P.J. \& Pandis, S.N., Impacts of climate change on regional and urban air quality in the eastern United States: role of meteorology. Journal of Geophysical Research, 114, D05308, 2009. http://dx.doi.org/10.1029/2008JD009849

[7] Pye, H.O.T., Liao, H., Wu, S., Mickley, L.J., Jacob, D.J., Henze, D.K. \& Seinfeld, J.H., Effect of changes in climate and emissions on future sulfate-nitrate-ammonium aerosol levels in the United States. Journal of Geophysical Research, 114, D01205, 2009. http://dx.doi.org/10.1029/2008JD010701

[8] Lam, Y.F., Fu, J.S., Wu, S. \& Mickley, L.J., Impacts of future climate change and effects of biogenic emissions on surface ozone and particulate matter concentrations in the United States. Atmospheric Chemistry and Physics, 11(10), pp. 4789-4806, 2011. http://dx.doi.org/10.5194/acp-11-4789-2011

[9] Gao, Y., Fu, J.S., Drake, J.B., Lamarque, J.F. \& Liu, Y., The impact of emission and climate change on ozone in the United States under representative concentration pathways (RCPs). Atmospheric Chemistry and Physics, 13, pp. 9607-9621, 2013. http://dx.doi.org/10.5194/acp-13-9607-2013

[10] Penrod, A., Zhang, Y., Wang, K., Wu, S.Y. \& Leung, R.L., Impacts of future climate and emission changes on U.S. air quality. Atmospheric Environment, 89, pp. 533-547, 2014. http://dx.doi.org/10.1016/j.atmosenv.2014.01.001

[11] Grell, G.A., Peckham, S.E., Schmitz, R., McKeen, S.A., Frost, G., Skamarock, W.C. \& Eder, B., Fully coupled "online" chemistry within the WRF model. Atmospheric Environment, 39(37), pp. 6957-6975, 2005. http://dx.doi.org/10.1016/j.atmosenv.2005.04.027

[12] Wang, K., Zhang, Y., Yahya, K., Wu, S.Y. \& Grell, G., Implementation and initial application of new chemistry-aerosol options in WRF/Chem for simulating secondary organic aerosols and aerosol indirect effects for regional air quality. Atmospheric Environment, 115, pp. 716-732, 2015.

http://dx.doi.org/10.1016/j.atmosenv.2014.12.007

[13] Moss, R.H., Edmonds, J.A., Hibbard, K.A., Manning, M.R., Rose, S.K., van Vuuren, D.P., Carter, T.R., Emori, S., Kainuma, M., Kram, T., Meehl, G.A., Mitchell, J.F.B., Nakicenovic, N., Riahi, K., Smith, S.J., Stouffer, R.J., Thomson, A.M., Weyant, J.P. \& Wilbanks, T.J., The next generation of scenarios for climate change research and assessment. Nature, 463, pp. 747-756, 2010.

[14] van Vuuren, D.P., Edmonds, J., Kainuma, M., Riahi, K., Thomson, A., Hibbard, K., Hurtt, G.C., Kram, T., Krey, V., Lamarque, J.-F., Masui, T., Meinshausen, M., Nakicenovic, N., Smith, S.J. \& Rose, S.K., The representative concentration pathways: an overview. Climate Change, 109, pp. 5-31, 2011. http://dx.doi.org/10.1007/s10584-011-0148-z

[15] Yan, F., Winijkul, E., Streets, D.G., Lu, Z., Bond, T.C. \& Zhang, Y., Global emission projections for the transportation sector using dynamic technology modeling. Atmospheric Chemistry and Physics, 14, pp. 5709-5733, 2014, 2014.

http://dx.doi.org/10.5194/acp-14-5709-2014

[16] Grell, G., Dudhia, J. \& Stauffer, D., A description of the fifth generation Penn State/ NCAR mesoscale model (MM5), in Tech. Rep. NCAR/TN-398+STR, Natl. Cent. for Atmos. Res., Boulder, Colo., 1994.

[17] Byun, D. \& Schere, K.L., Review of the governing equations, computational algorithms, and other components of the models-3 Community Multiscale Air Quality (CMAQ) modeling system. Applied Mechanics Reviews, 59, pp. 51-77, 2006.

http://dx.doi.org/10.1115/1.2128636 
[18] Zhang, Y., Online coupled meteorology and chemistry models: history, current status, and outlook. Atmospheric Chemistry and Physics, 8, pp. 2895-2932, 2008. http://dx.doi.org/10.5194/acp-8-2895-2008

[19] Glotfelty, T., He, J. \& Zhang, Y., The impact of future climate policy scenarios on air quality and aerosol/cloud interactions using an advanced version of CESM/CAM5, in preparation, 2016a.

[20] He, J. \& Zhang, Y., Improvement and further development in CESM/CAM5: gas-phase chemistry and inorganic aerosol treatments. Atmospheric Chemistry and Physics, 14, pp. 9171-9200, 2014. http://dx.doi.org/10.5194/acp-14-9171-2014

[21] Gantt, B., He, J., Zhang, X., Zhang, Y. \& Nenes, A., Incorporation of advanced aerosol activation treatments into CESM/CAM5: model evaluation and impacts on aerosol indirect effects. Atmospheric Chemistry and Physics, 14, pp. 7485-7497, 2014. http://dx.doi.org/10.5194/acp-14-7485-2014

[22] Glotfelty, T., He, J. \& Zhang, Y., New organic aerosol treatments in CESM/CAM5: development and initial application, in preparation, 2016b.

[23] Zhang, Y., Liu, P., Pun, B. \& Seigneur, C., A comprehensive performance evaluation of MM5-CMAQ for summer 1999 southern oxidants study episode, part-i. evaluation protocols, databases and meteorological predictions. Atmospheric Environment, 40, pp. 4825-4838, 2006.

http://dx.doi.org/10.1016/j.atmosenv.2005.12.043

[24] Zhang, Y., Vijayaraghavan, K., Wen, X.Y., Snell, H.E. \& Jacobson, M.Z., Probing into regional ozone and particulate matter pollution in the United States: 1. A 1-year CMAQ simulation and evaluation using surface and satellite data. Journal of Geophysical Research, 114, D22304, 2009. http://dx.doi.org/10.1029/2009JD011898

[25] Zhang, Y., Karamchandani, P., Glotfelty, T., Streets, D.G., Grell, G., Nenes, A., Yu, F.Q. \& Bennartz, R., Development and initial application of the global-through-urban weather research and forecasting model with chemistry (GU-WRF/Chem). Journal of Geophysical Research, 117, D20206, 2012. http://dx.doi.org/10.1029/2012JD017966

[26] Yahya, K., Wang, K., Campbell, P., Glotfelty, T., He, J. \& Zhang, Y., Decadal evaluation of regional climate, air quality, and their interactions using WRF/Chem. Geoscientific Model Development, 9, pp. 671-695, 2016a. http://dx.doi.org/10.5194/gmd-9-671-2016

[27] Yahya, K., Campbell, P., Chen, Y., Glotfelty, T., He, J. \& Zhang, Y., Downscaling CESM using WRF/Chem: decadal application for regional air quality and climate modeling over the U.S. under the representative concentration pathways scenarios, in preparation, $2016 b$.

[28] Wang, K., Zhang, Y., Yahya, K. \& Campbell, P., Decadal application of WRF/Chem under current and future climate/emission scenarios, Part I: simulation design, evaluation, and sensitivity simulations, in preparation, 2016.

[29] Jena, C., Wang, K., Zhang, Y., Campbell, P., Yahya, K., Yan, F. \& Streets, D., Decadal application of WRF/Chem under current and future climate/emission scenarios, Part II: impacts of climate and emission changes on regional meteorology and air quality, in preparation, 2016. 